\title{
Male Agency and Masculine Performance in the Baal Cycle
}

\section{Nissinen, Martti}

Brill

2020

Nissinen, M 2020 , Male Agency and Masculine Performance in the Baal Cycle . in S Russell \& E Hamori (eds), Mighty Baal : Essays in Honor of Mark S. Smith . Harvard Semitic pÿStudies , no. 66 , Brill , Leiden , pp. 4771 . https://doi.org/10.1163/9789004437678_005

http://hdl.handle.net/10138/325766

https://doi.org/10.1163/9789004437678_005

acceptedVersion

Downloaded from Helda, University of Helsinki institutional repository.

This is an electronic reprint of the original article.

This reprint may differ from the original in pagination and typographic detail.

Please cite the original version. 
Male Agency and Masculine Performance in the Baal Cycle

Martti Nissinen

\title{
1. Male Agency and Masculine Performance
}

\author{
abdy $d$ ymlk I ilm I myself am the one who reigns over the \\ gods, \\ I ymru ilm w nšm Indeed orders for gods and mankind, \\ $d y s ̌ b\left[{ }^{~}\right]$ hmlt ars $\quad$ Who satis[fies] the multitudes of the Earth. ${ }^{1}$
}

These words are quoted from the Baal Cycle, the largest narrative composition from Ugarit. They are pronounced by Baal, one of the major deities featuring in the Ugaritic texts, ${ }^{2}$ whose name $b \%$ means "lord" and who is called by epithets such as aliyn bl "the Mightiest Lord," aliy qrdm "the Mightiest of Heroes," dmrn "the Powerful One," and even bl ugrt "the Lord of Ugarit." Baal is portrayed as a

\section{${ }^{1}$ KTU 1.4 VII 49-52.}

Formatted: English (United States)

\footnotetext{
${ }^{2}$ For Baal and the Baal Cycle, see the many works of Mark Smith, e.g., Smith 1986; 1994; 1997; 1998; 2001; 2003; 2014; Smith and Pitard 2009.
} 
king enthroned on Mount Sapan, and he is known as a vigorous weather god, an abundant provider of rain and agricultural fertility with remarkable sexual performance. Moreover, he appears as a club-wielding hero and defeater of the powers of death, as a god who dies but returns to life. If this was his full portrait, Baal could be regarded as the paragon of masculinity, indeed a he-man among the gods. However, the Ugaritic myth does not let his high position among the gods emerge easily, quite to the contrary. Despite his self-assertive speech, his position in the divine realm is anything but stable and he finds himself in precarious positions. Therefore, Baal is not depicted as being constantly fearless or impassive:
yraun aliyn b\%
The Mightiest Baal is afraid,
$\underline{t} t^{\prime} n n r k b$ 'rpt
The Rider-of-the-Clouds is scared. ${ }^{3}$

Baal has to fight for his position, and his success is dependent on the assistance of other divine beings, male as well as female. In fact, the longest literary composition related to Baal, the Baal Cycle (KTU 1.1-6), is not all about Baal's uncontested superiority over gods and mankind. It could rather be read as a

${ }^{3}$ KTU 1.5 II 6-7. 
story of divine rivalry, of the unpredictability of divine decisions-and, evidently, of the gendered imagination of what may take place in the superhuman realm. Indeed, Mark Smith says, "Gender is key."

However, there is surprisingly little gender-related research on Ugaritic texts. ${ }^{5}$ The issue of masculinity has been raised especially with regard to the goddess Anat, whose performance has been found violent enough to be characterized as masculine. ${ }^{6}$ The topic of masculinity has made its way rather slowly into ancient Near Eastern studies, "an intellectually conservative discipline," 7 but it started emerging strongly about a decade ago, first among

\footnotetext{
${ }^{4}$ Smith 2014, 175.

${ }^{5}$ See, however, some important works on women in Ugarit: Marsman 2003; Thomas 2019; as well as the recent study on gender in the poem of Aqhat in Budin 2018, and the analysis of the relationship of Baal and Anat in Juloux 2016. For the sexual relations between Ugaritic deities, see Smith 2008; for gender roles in Ugaritic texts, see Smith 2014, 162-82.

${ }^{6}$ See, e.g., Walls 1991; Day 1991; Guest 2016, 73-75.

${ }^{7}$ Asher-Greve 2018, 37; cf. Zsolnay 2018. Earlier studies on men and masculinity in the ancient Near Eastern sources and the Hebrew Bible include, e.g., Clines 1995, 212-43; Washington 1997; Nissinen 1998; Cooper 2002; Chapman 2004.
} 
biblical scholars ${ }^{8}$ and recently even on the larger Near Eastern scene. ${ }^{9}$ Thanks to this development, we can now study masculinities and male agencies in ancient Near Eastern source materials with sharper analytical tools. The multifaceted image of Baal and his relationships with other male and female deities in the Baal Cycle makes this text a good starting point for the study of masculinity in Ugaritic literature.

The foremost theoretical paradigm in masculinity studies in general has been the multiple masculinities theory that emerged in 1980s and 1990s and gradually found its way even to biblical and ancient Near Eastern scholarship. ${ }^{10}$ This theory builds on the concepts of hegemonic masculinity, the cultural ideal of male performance in a male-dominated society defined and legitimated by those

${ }^{8}$ Several collections of essays have appeared within the past fifteen years on men and masculinity in the New Testament and Early Christianity, as well as in the Hebrew Bible; see Moore and Anderson 2003; Krondorfer 2009; Creangă 2010 and 2019; Creangă and Smit 2014.

${ }^{9}$ Zsolnay 2017; Svärd and Garcia Ventura 2018 (especially N'Shea 2018 and Svärd and Nissinen 2018); Peled 2016.

${ }^{10}$ See Stephen Wilson's recent analysis of the use of the multiple masculinities theory in the study of the Hebrew Bible (Wilson 2019; cf. Macwilliam 2019). 
in privileged positions of power, and complicit masculinity, that is, the masculine performance of men who are not able to live up the ideal but who nevertheless support the hegemonic ideal. ${ }^{11}$ Since the hegemonic model, which as such is variable, ${ }^{12}$ may fail to make visible the articulations of masculinity that do not conform to the hegemonic ideal, Raewyn Connell categorized two further types of masculinity: subordinate masculinity signifying a lower status in masculine hierarchy, lacking some crucial characteristics of hegemonic masculinity, and marginal masculinity, which is a non-authorized type of male performance that appears as illegitimate for the dominant group and is typically associated with some kind of male otherness. ${ }^{13}$

Even if multiple masculinities are recognized, the different forms of masculinity are defined in relation to hegemonic male performance-the complicit and subordinate type in terms of male hierarchy and the marginalized type in terms of authorization. The yardsticks of masculinity have usually been

\footnotetext{
${ }^{11}$ See Carrigan, Connell, and Lee 1985; Connell 2005; Connell and
} Messerschmidt 2005.

${ }^{12}$ For multiple competing hegemonic masculinities, see, e.g., Asikainen 2014, 157-61.

13 Connell 2005, 67-86. 
found in the presence of some typical indicators of hegemonic masculinity, such as physical strength and military prowess; wisdom and persuasive speech; handsome looks and beauty; self-reliance and non-dependence on women. ${ }^{14}$ Further items on the list of ideal masculinity could include self-control; fertility and procreation; and male honor. ${ }^{15}$ All these features can be found in the sources describing male performance positively; therefore, they could be understood as constituents of ideal masculinity from the sources' point of view.

There is, however, the risk of introducing a high degree of gender essentialism into the analysis, especially if certain features of masculine performance (that is, action typical to male characters) are understood as reflecting the status of "manhood" or male identity, "a stable, sexed core to which attributes or gendered practices are affixed." ${ }^{16}$ Defining gender identity by gendered performance and vice versa leads to circular reasoning. ${ }^{17}$ Therefore, it is necessary to de-essentialize the concept of "masculinity," using the adjective

\footnotetext{
${ }^{14}$ These are the characteristics of masculinity Clines 1995: 212-15 identified in the description of the young David in 1 Samuel 16.

${ }^{15}$ Cf. Wilson 2019, 26-27.

${ }^{16}$ Guest 2011, 12 n. 13 .

${ }^{17}$ Butler 1990, 25.
} 
"masculine" to reflect a socially (and textually) contingent expectation of male performance, and the adjective "male" as denoting actors that are identified by their male gender in the sources. Hence, even the performance of non-male characters can be characterized as masculine if it corresponds to the expectation of what men typically do. Performance, on the other hand, is related to but not to be equated with agency, by which I mean the initiative, motivation, and purpose of the action of an individual, whether male or non-male. Male agency, hence, refers exclusively to the action of a character identifiable as male.

In the following, I will read the Baal Cycle through the lens of male agency, that is, the action of the divine male characters, and masculine performance, or ways of operation conventionally perceived of as being typical for men's behavior. The purpose of the analysis is not only to trace different forms of masculinity in the Baal Cycle but also to test the applicability of the theory of multiple masculinities to a literary work whose protagonists act on a superhuman stage. I will restrict my focus to the Baal Cycle only, even though it can be assumed that the masculinities of Ugaritic deities may be constructed differently in other texts. I also leave aside religio-historical and socio-political issues, such as the emergence and status of Baal in the Ugaritic pantheon ${ }^{18}$ and

\footnotetext{
${ }^{18}$ Cf., e.g., Smith 2003.
} 
the relationship between the text and the political circumstances in the time of its writing. ${ }^{19}$

As this article is a grateful tribute to Mark Smith, my dear friend and honored colleague, I follow his reconstruction of the order of the tablets and columns of the original text $\mathrm{t}^{20}$ and, in general, his English translations of Ugaritic.

\section{Male and Female Agents in the Baal Cycle}

\subsection{Baal versus Yamm (KTU 1.1-2)}

The modern reader of the Baal Cycle has to wait quite a while for the appearance of Baal on the stage. We do not know how Baal was introduced in

${ }^{19}$ E.g., Tugendhaft 2018.

${ }^{20}$ See Smith 1994; 1997; Smith and Pitard 2009. The references to the Ugaritic text are made to KTU (Dietrich, Loretz, and Sanmartín 2013), in which the numbering of columns in KTU 1.1 and 1.2 is in reversed order compared to Smith's reconstruction. Many suggestions have been made to reconstruct the original order of the tablets; compare, for example, de Moor (1987) who reads the tablets in the following order: KTU 1.3-1-2-4-5-6. For further suggestions, see Smith 1994, 2-25; Pardee 2012. 
the beginning of the composition. The first column of the original text is lost, and the preserved part of the text begins with a very fragmentary dialogue between the supreme god El and another speaker, often identified with Yamm, the god of the Sea, ${ }^{21}$ concerning someone to be attacked. In the next scene, a divine council has gathered for a feast in which $\mathrm{El}$, according to the most common interpretation, elevates Yamm, the "Beloved of El" (mdd il) over the other gods. ${ }^{22}$ It seems, however, that Baal has got El's "house of silver" in his possession, which indicates a dominant role among the gods. El sees him as a usurper who needs to be ousted from this undeserved position:

${ }^{21}$ Thus Smith 1994, 120-31.

22 That the "Beloved of El" is to be identified with Yamm depends on the fragmentary lines KTU 1.1. IV 14-15: šm bny yw ilt[...] w p'r šm ym[...] translated as "The name of my son is(?) Yw, O Elat [...], and he pronounces the name Yamm" (translation Smith 1994, 132). The position given to Yamm is interpreted in terms of royal succession (Pitard 2013), either as coronation (Wyatt 2005, 1720) or as royal adoption (Töyräänvuori 2017; 2018, 229-38); cf. Smith and Pitard 2009, 247 who talk about the "proclamation of Yamm as the head of the council." 


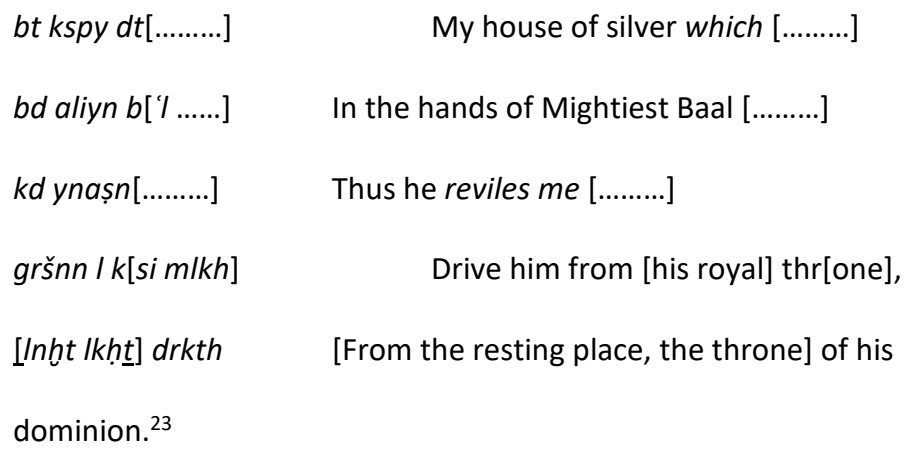

El's pronouncement introduces a series of power struggles, which constitute the main storyline of the composition. In the rest of the narrative, hierarchy in the divine world is a continuous theme, which makes it possible to read the entire work as an apotheosis of hegemonic masculinity.

In the beginning, El appears as the dominant male god. His agency and performance are presented as authoritative, he is the one who presides over the divine assembly and gives orders to Yamm. Sitting at the top of the divine hierarchy, El does not take direct action against Baal but acts through ancillary characters. His plan is to depose Baal by promoting Yamm, demonstrating this by building a palace for Yamm. Interestingly, Yamm himself is not given any

${ }^{23}$ KTU 1.1 IV 21-25. Due to the damages of the text, the verse structure cannot be reliably reconstructed. 
assignment after he is initially ordered to drive Baal from his throne. For a long time, Yamm remains in the background, having no influence on the execution of the divine plan. This, on the one hand, may indicate his high position as a god who does not need to get his own hands dirty, but at the same time, such a passive role deprives him of active agency and underlines his subordination to El. It is El and not Yamm who sends messengers to Kothar-wa-Hasis, the divine craftsman, who receives a mysterious word from El. The message is attractive enough for him to make his way to El's abode from far away. The domicile of Kothar-wa-Hasis is expressed with the parallelism of Kaphtor and Memphis, which stands for a long distance rather than for a precise location, and points to his "foreign" origin and his position outside of the inner circle of the pantheon. ${ }^{24}$ El does not address Kothar-wa-Hasis in an authoritative manner; his invitation is not an order but sounds more like a tempting proposal:

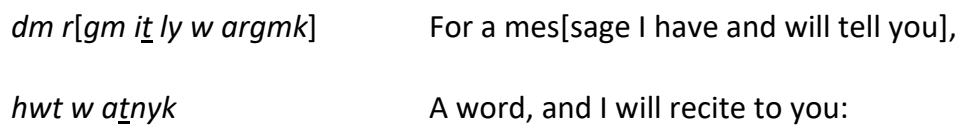

\footnotetext{
${ }^{24}$ Cf. Smith 1994, 167: "The double abodes have been explained as reflexes of metal and craft trade from Egypt and the Mediterranean Sea to Ugarit, as Kothar is imputed to be their divine patron."
} 


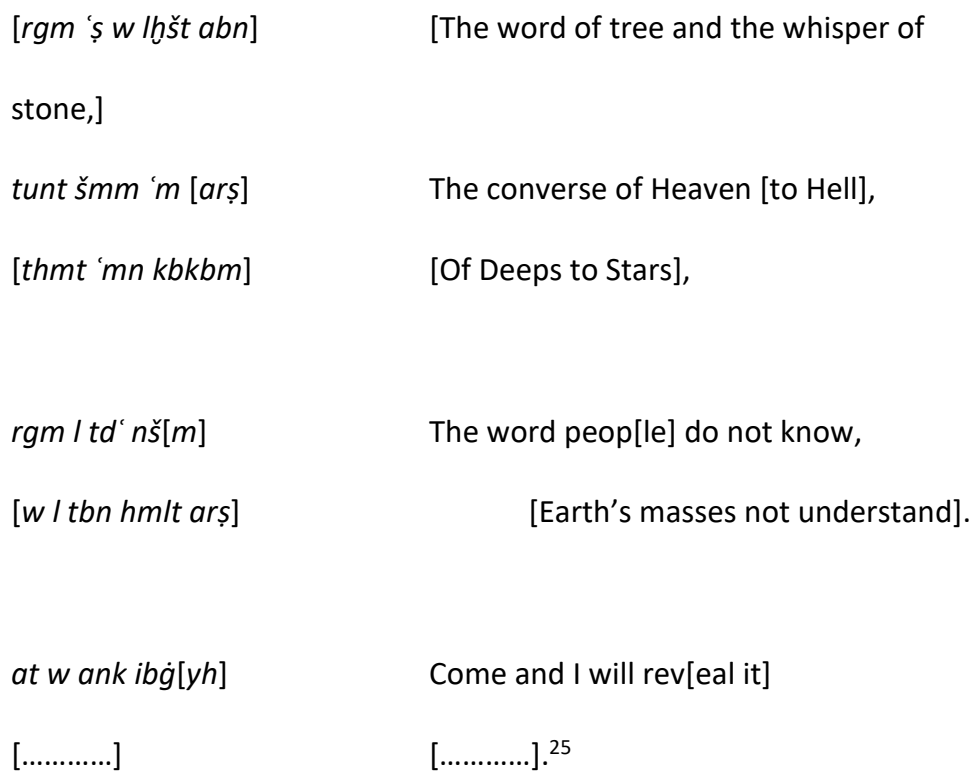


but El's messengers also prostrate themselves before Kothar-wa-Hasis. ${ }^{27} \mathrm{His}$ agency is rather that of an external expert or a business partner.

The next move of $\mathrm{El}$ is to send messengers again, this time to his daughter Anat. Both the message itself and its position in the composition are somewhat unclear, but El seems to offer his daughter the role of a pacifier, perhaps anticipating the combat to follow. ${ }^{28}$ In any case, Anat will not appear for a long while, and important twists and turns take place before she starts fulfilling this function. Meanwhile, two deities are introduced: Shapsh, the female sun god, and Athtar, the son of El. Shapsh warns Athtar that El may displace him in favor of Yamm; how she knows about this remains unclear-perhaps because of the damage of the lines preceding this episode, or because the role of Shapsh as the intermediary of El's words is presupposed:

$\begin{array}{ll}{[i k a] / y s ̌ m ' k} & \text { How will he hear you, } \\ \operatorname{tr}[i] l a b k & \text { Bull El, your father? }\end{array}$

\footnotetext{
${ }^{27}$ KTU 1.1 III 2-3 (messengers prostrate themselves before Kothar-wa-Hasis); 1.1

III 24-25; 1.2 III 5-6 (Kothar-wa-Hasis prostrates himself before EI).

${ }^{28} \mathrm{KTU} 1.1 \mathrm{II}$; a major portion of the text is missing from the preserved tablet.
} 
Iys' $[a] / t \underline{t} b t k$

throne,

ly[hpk ksa] mlkk

kingship,

I ythbr ht mtpțk
Surely, he will remove the support of your

Surely, he will ov[erturn the seat of] your

Surely, he will break the scepter of your

rule. $^{29}$

Having heard Shapsh's warning, Athtar is ready to descend from his position and humble himself in the palace of Yamm, which he describes as the place where he (or his dead body) will be washed. ${ }^{30} \mathrm{It}$ is noteworthy that Athtar capitulates immediately without a word of opposition or defense. He does not question Shapsh's information, but believes that he has been superseded by his father and acquiesces in subordination, not only to El but also to Yamm. He gives up every type of agency and assumes the passive role assigned to him in the divine spectacle orchestrated by El on behalf of Yamm.

${ }^{29}$ KTU 1.2 III 17-18.

${ }^{30}$ KTU 1.2 III 19-21. The subject of the washing may be translated as servants (ktrrm); cf. Smith 1997, 97: "Kothar shall wash me." 
The voice of Baal, the actual object of El's anger, is heard for the first time when he addresses Yamm, possibly through the mouth of his messengers, with a devastating message, wishing that Horon (?) and Athtart would break his head. This is the first reaction of Baal to the plot of El to depose him, but it is not revealed to the reader how he has become cognizant of it, unless the destroyed parts of the text contained this information. Yamm's reaction to Baal's outburst is a derisive laugh. He does not answer Baal directly but sends messengers to El and his divine council, in which even Baal is present. Bypassing Baal and going straight to El indicates that Yamm wants to appear to other gods as superior to Baal, and his arrogance does not stop there: he tells his messengers not to bow down to El's feet but to deliver his message standing:

$\begin{array}{ll}\text { thm ym b'lkm } & \text { Decree of Yamm, your Master, } \\ \text { adnkm tpt [nhr] } & \text { Your Lord, Judge [River]: } \\ \text { tn ilm } d \text { tqh } & \text { "Give up, O Gods, the one you obey, } \\ d \text { tqyn hmlt } & \text { The one you obey, O Multitude! }\end{array}$




$$
\begin{array}{ll}
\text { tn } b l\left[w^{i} n n h\right] & \text { Give up Baal [that I may humble him], }{ }^{31} \\
\text { bn dgn artm p } \underline{d} h & \text { The Son of Dagan that I may possess his }
\end{array}
$$

gold." 32

Yamm's messengers arrive as the council of gods is sitting at a meal, and their arrival makes the gods immediately lower their heads on top of their knees. Baal, who is waiting on El during the meal, reacts aggressively and tells them to raise their heads, first saying that the gods should answer the messengers together (ahd ilm t'ny) but then taking the initiative himself: "I myself will answer Yamm's messengers" ( $w$ ank 'ny mlak ym)..$^{33}$ Again, the gods react instantly, raising their heads from the top of their knees. Yamm's messengers, following his orders, do not prostrate themselves before $\mathrm{El}$ and the divine council but deliver their speech standing. El gives his approval to Yamm's request without the slightest hesitation:

'bdk bly ymm Your slave is Baal, O Yamm,

\footnotetext{
${ }^{31}$ Restoration according to KTU 1.2 I 35.

${ }^{32}$ KTU 1.2 I 17-19.

${ }^{33}$ KTU 1.2 I 24-28.
} 
'bdk b'l[nhr]m

bn dgn asrkm
Your slave is Baal, O [River],

The Son of Dagan, your captive. ${ }^{34}$

Even Baal does not vacillate but strikes down Yamm's messengers, until Anat and Athtart stop him and seize his hands. What is left of the column begins Baal's threatening message, probably meant to be delivered by Yamm's messengers to him.

A long break in the text prevents us from knowing the most immediate consequences of Baal's actions before the divine council. To the modern reader it comes as a surprise that Kothar-wa-Hasis has meanwhile come to Baal's side, acknowledging his kingship:

\begin{tabular}{|c|c|}
\hline$|\mathrm{rgmt}| \mathrm{k}|\mathrm{zb}| \mathrm{b} \mid$ & Indeed, I tell you, Prince Baal, \\
\hline tnt / rkb 'rpt & I recite, O Cloudrider: \\
\hline ht ibk bim & Now your enemy, Baal, \\
\hline ht ibk tmhș & Now smash your enemy, \\
\hline ht tșmt șrtk & Now vanquish your foe! \\
\hline
\end{tabular}

Formatted: English (United States)

${ }^{34}$ KTU 1.2 I 36-37. 


$\begin{array}{ll}{[\ldots]} & {[\ldots]} \\ \text { tqh } m l k \text { Imk } & \text { So assume your kingship, } \\ d r k t d t d r d r k & \text { Your everlasting dominion. }{ }^{35}\end{array}$

Kothar-wa-Hasis designs two powerful weapons, the clubs called Yagarrish and Ayyamarri, for Baal to attack Yamm. ${ }^{36}$ By the first strike, Yamm does not die, but with another try, Baal turns out victorious:

yprsh ym yql l arș Yamm collapses and falls to the earth,

tngṣn pnth His joints shake,

w ydlp tmnh And his form collapses.

yqt $b \%$ wšt ym Baal drags and dismembers Yamm,

ykly tpt $n h r \quad$ Destroys Judge River. ${ }^{37}$

${ }_{4}^{35} K T U 1.2$ IV 7-10.

Formatted: English (United States)

\footnotetext{
${ }^{36}$ Baal appears as a club-wielding hero even in images; for the iconography of Baal, see Cornelius 1994.

${ }_{4}^{37} K T U 1.2$ IV $25-27$.
}

Formatted: Polish 
The rest of the tablet is difficult to read, but it seems like the death of Yamm and the rule of Baal is now acknowledged by other gods.

The positions of the male characters in the scene at the divine council's meal and the subsequent fight between Baal and Yamm form an interesting network of masculine performances. Yamm behaves consciously in an outrageously arrogant way, naming himself the lord of the gods and expressing his desire to humble Baal who, on the other hand, despite his subservient position as El's waiter, rebukes the other gods for kowtowing to Yamm's messenger and violently opposes El's decision to deliver him into Yamm's hands. El himself does not appear to be offended by the haughty behavior of Yamm's messengers, neither does he (at least according to the preserved part of the text) react to Baal's unauthorized reproach and impulsive violence but simply confirms Yamm's message. The rest of the gods behave like puppets, bowing and raising their heads whenever prompted.

Yamm only takes part in the scene at the divine council verbally: he acts from a distance and his hegemony is based on persuasive speech through his messengers' tongues, which act like a "sharp sword" (ḥrb Ițšt [lš $]$ nhm) $)^{38}$ When eventually confronted by Baal, Yamm, however, is unable to defend himself

\footnotetext{
${ }^{38} \mathrm{KTU} 1.2$ I 33.
} 
against Baal's superior military technology and is destroyed and humiliated by him. El maintains his position as the supreme god and executes his power. The reader might wonder whether $\mathrm{El}$ is being conned by Yamm to passively consent to his supercilious demand, but this may be interpreted as a part of the initial plot of El and Yamm. Baal is the one who is defiant and takes initiative, defending himself without asking for permission and refusing to submit to Yamm. Baal's agency is the most active of all characters involved in the divine scene. He manages to win Kothar-wa-Hasis to his side by whatever means, perhaps recounted in the destroyed part of the text, and due to his own determination combined with superior armature, he turns out victorious in his battle against Yamm. Thus, El executes hegemonic masculinity by his authority, Yamm by his arrogant speech, and Baal by his headstrong refusal and violent action.

Baal's initially subservient position does not result in subordinate agency; this role is reserved for Yamm's messengers who do not have any independent agency, and to the members of the divine council who play an outspokenly passive part in the scene. Only the female gods Anat and Athtart are mentioned by name, and they are the only ones among the gods to act, preventing Baal from killing Yamm's messengers and engaging in a distinctly masculine performance by using physical force. When Baal eventually goes off to confront 
Yamm, Athtart first seems to doubt his success, but when Yamm eventually lies on the ground, she incites Baal to scatter his dismembered body. ${ }^{39}$

Kothar-wa-Hasis appears once more in a role that enables him to proclaim Baal's kingship without actually submitting to him. Again, his agency is that of an outsider who is neither part of the divine council nor dependent on its decisions. He is consulted in professional matters, his function is restricted to special assignments, he is free to choose his business partners, and he is not involved in competition. This gives him an independent agency, which he executes by his skill, not by overtly masculine performance.

\subsection{Baal's Palace (KTU 1. 3-4)}

If the storyline ended with Baal's victory over Yamm, Baal could well be described as the epitome of hegemonic masculinity who rises to power, slays his rivals, and demonstrates his unsurpassed heroism. However, Baal's aspirations for power are not yet satisfied, and this causes him eventually to engage in a new battle, this time with Mot, the god of the Netherworld.

After defeating Yamm, Baal finds himself hosting a victory feast on the summit of Sapan, and an anonymous male character is serving him as he himself

\footnotetext{
${ }^{39}$ Cf. KTU 1.2 IV 6-7 and 28-30.
} 
was previously waiting on El. Wine is consumed, music is played, and Baal is watching his two daughters, Pidray and Tallay. ${ }^{40}$ This harmonious scene is disconnected from the continuation of the narrative by a major break, leaving Baal enjoying his newly acquired hegemonic position. The following section tells about the goddess Anat, giving a heated description of her "battles between two towns":

\begin{tabular}{|c|c|}
\hline w hln 'nt tm thṣ b 'mq & And look! Anat fights in the valley, \\
\hline thtșb bn qrytm & Battles between two towns. \\
\hline tmbș lim hpym & She fights the people of the seashore, \\
\hline tșmt adm șat špš & Strikes the populace of the sunrise. \\
\hline tḥth k kdrt riš & Under her, like balls, are heads, \\
\hline Ih k irbym kp & Above her, like locusts, hands, \\
\hline k qșm ǵrmn kp mhr & Like locusts, heaps of warrior-hands. ${ }^{41}$ \\
\hline
\end{tabular}

\footnotetext{
${ }^{40}$ KTU 1.3 I (lines from both the beginning and the end of the column are missing, altogether about 40 lines).

${ }^{41}$ KTU 1.3 II 5-11.
} 
Anat's fantastic universal war against anonymous enemies ${ }^{42}$ is described in extremely brutal terms. Her combativeness is so insatiable that she continues the bloody battle in her own palace between chairs and tables until she eventually cleans the palace and makes herself beautiful. Meanwhile, Baal's feast continues with songs of love of himself and his three daughters; even the third daughter, Arsay, is mentioned here. Baal wants to send a message to Anat, inviting her to hear, "the word of tree and the whisper of stone, the converse of Heaven with Hell, of Deeps with Stars." 43 Baal's two messengers, Gapn and Ugar, come to Anat whose initial reaction is described in bodily terms, her loins trembling and her face sweating. ${ }^{44}$ Anat believes that Baal has been attacked by an enemy, and recounts her own victorious battles against all divine and mythical foes. The message, however, comes as a relief to her and she accepts

${ }^{42}$ The seashore and the sunrise represent the west and the east, "perhaps a merismus suggesting the world-wide extent of her fighting" (Smith 1997: $167 \mathrm{n}$.

45.)

${ }^{43}$ KTU 1.3 III 22-25. The wording is the same as in El's message to Kothar-waHasis above.

${ }^{44}$ KTU 1.3 III 32-34. 
Baal's invitation; the two deities have a joyful, perhaps even intimate, encounter. ${ }^{45}$ The rest of the column is damaged, but what is left of the text suggests that their conversation has turned into the topic that may be the actual message of, "the word of tree and the whisper of stone": Baal has no palace but has to dwell with El and Athirat. Anat gets furious and rushes to El, threatening to smash his head:

$\begin{array}{ll}a m b s ̦[\ldots] q d q d k & \text { I will smash [...] your crown, } \\ \text { ašhlk šbtk }[d m m] & \text { I will make your beard run with blood, } \\ \text { šbt qdnk mm'm } & \text { The gray hair of your beard with }\end{array}$

gore. $^{46}$

El answers peacefully, asking what makes Anat so furious, and she, in a much more respectful tone, recounts the lament of Baal that he does not have a palace of his own. The destroyed part of the text probably contains El's refusal, because Baal, once again, sends messengers to Kothar-wa-Hasis, "the Fisher of

\footnotetext{
${ }^{45}$ KTU 1.3 IV 37-46.

${ }^{46} K T U 1.3 \mathrm{~V} 23-25$.
} 
Athirat" (dgy atrt) ${ }^{47}$ asking him to produce a precious gift for Athirat, whom Baal wants to win over on the palace issue. Kothar-wa-Hasis casts a set of grandiose items of silver and gold with precious decorations, ${ }^{48}$ and Baal and Anat go to the Creatress of Gods with these gifts. Athirat, in the middle of domestic activities as the divine housewife, is at first shocked, as Anat was earlier, because she believes they have come with violent intentions. But she becomes immediately enchanted by the prestigious gifts.

The damage to the text makes it difficult to follow the plot at this point; in any case, Baal recounts the humiliation he had suffered in the divine council while Athirat asks why they have approached her instead of El, the Creator of Creatures. What follows in the extant part of the text suggests that Anat and Baal have succeeded in persuading Athirat to turn to El on their behalf in the matter of Baal's palace. Athirat travels to El on a donkey tied by her servant Qudsh-wa-Amrar, she enters his abode and prostrates herself before him. El is delighted to receive her and is ready to provide her with food, drink, and intimacy:

\footnotetext{
${ }^{47}$ KTU 1.3 VI 10.

${ }^{48}$ KTU 1.4 I 23-43.
} 


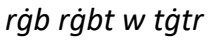

$h m$ ġmu ġmit $w$ 's[t]

Iḥm hm štym

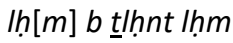

št b krpnm yn

$b k<s>h b r s+d m$ 'șm

hm yd il mlk yhssk

you,

ahbt tr t'rrk
Are you very hungry, having traveled?

Or are you very thirsty, having jour[neyed]?

Eat or drink:

$E[$ at] food from the tables,

Drink wine from goblets,

From a golden c<up $>$, the blood of trees!

Or does the "hand"49 of El the King excite

The love of Bull arouse you ${ }^{50}$

Athirat addresses El most reverentially, praising his wisdom but also referring to Baal as "our ruler, with none above him" (țptn in $d$ 'Inh), which is interesting with regard to El's position as the supreme god and with regard to the reason for

\footnotetext{
${ }^{49}$ As the parallelism with ahbt "love" indicates, yd "hand" stands for the male organ.

${ }^{50}$ KTU 1.4 IV 34-39.
} 
Athirat's speech. She recounts to him Baal's complaint about not having a palace, upon which El replies:

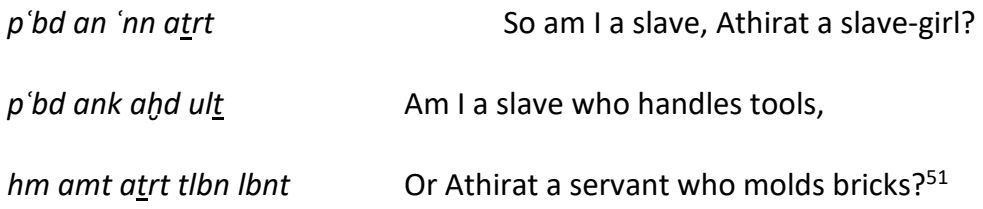

Such a reaction could preclude an absolute rejection of Baal's request by El who would have every reason to be offended. Surprisingly, however, he gives his immediate consent for Baal's palace to be built. Athirat replies with renewed praise of his wisdom and its indicators, his grey hair and long beard, and she sends word to Baal, authorizing the construction of a house with silver, gold, and purest lapis lazuli. The good tidings are brought to Baal by Anat (rather than by Athirat), and Baal receives them with great joy, sending right away for Kotharwa-Hasis who comes, is treated with ox and fatling by Baal, and is seated on a throne placed on his right side for negotiations.

The only problem concerns the window that Kothar-wa-Hasis suggests be installed in the house. Baal rejects this suggestion twice, even though Kothar-wa-

\footnotetext{
${ }^{51}$ KTU 1.4 IV 59-62
} 
Hasis predicts that he will change his mind: "You will return, O Baal, to my word" (tțb bl/ hwty). ${ }^{52}$ Within seven days, Kothar-wa-Hasis constructs the palace and Baal rejoices:

$\begin{array}{ll}<b>h t y b n t d t k s p & \text { My house I have built of silver, } \\ h k l y d t m \text { hrș } & \text { My palace of gold. }{ }^{53}\end{array}$

Once the palace is standing, Baal celebrates by not only arranging an extravagant banquet for the divine council but even making a grand tour through ninety cities. Eventually, to the great delight of Kothar-wa-Hasis, and without giving any reasons for his changed opinion, he says that he will install the window according to Kothar's advice. The window is a break in the clouds, through which Baal's mighty voice is carried forth, scaring his enemies who flee to distant places. Encouraged by this Baal decides to send a word to Mot, reminding him of who is now holding sway in the divine realm:

${ }^{52}$ KTU 1.4 VI 2, 15; cf. VII 23-25.

${ }^{53}$ KTU 1.4 VI 36-38. 
gods,
I ymru ilm w nšm
Indeed orders for gods and men,
d yšb[ ] hmlt arș
Who satisfy[ies] the multitudes of Earth. ${ }^{54}$

Baal's message to Mot triggers a new power struggle which is the topic of the last section of the Baal Cycle.

The palace episode KTU 1.3-4 differs from the first part of the Baal Cycle, the story of the combat of Baal and Yamm (KTU 1.1-2) by highlighting the role of the female deities Anat and Athirat. It is indeed female rather than male agency that guides the narrative forward. Baal's aspirations would lead nowhere without the help of both goddesses who, however, act in distinctly different ways. Anat's performance is characterized by features of hegemonic masculinity developed to the utmost, at least when it comes to martial prowess. She is an insatiable, even bloodthirsty warrior who seems to fight out of a passion for fighting. She takes the credit for finishing off not only Yamm, who had just been killed by Baal, but even other superhuman beings, ${ }^{55}$ thus appearing as Baal's

\footnotetext{
${ }^{54}$ KTU 1.4 VII 49-52.

${ }^{55}$ KTU 1.3 III 38-47.
} 
peer, if not as his potential rival. However, she decides to side with Baal and advance his case with the palace, but her aggressive strategy of approaching El does not bring the looked-for result. She behaves like a single hero whose action is impulsive rather than strategic. She can afford this because she is neither wife nor mother. ${ }^{56}$ Athirat's performance is different in many ways. She is found in her domestic chores, being all the time "servile before Bull El the Beneficient" (t'pp tr il dpid), and is thus introduced as performing the role of the archetypal housewife. This does not indicate any kind of passivity, though-on the contrary, Athirat takes initiative, heads out for El and, approaching him in a most reverent manner, succeeds in persuading him to give an order to construct a palace for Baal, something that Anat's masculine performance was unable to achieve. Of the two kinds of female agencies, the one of Athirat clearly works better for Baal.

Male agencies in the palace episode are somewhat overshadowed by the female characters' efficient action. Baal's victory over Yamm does not fulfill his aspirations for power. Despite his success in battle, he is not able to gain the prominence he wants to have among gods without the assistance of other gods.

\footnotetext{
${ }^{56}$ Her title bt/t refers to a young woman of marriageable age who has not yet borne children; see Day 1991; Walls 1991, 217-24.
} 
The martial kind of approach needs to be replaced with a diplomatic one, which requires Baal to stay where he is and act through messengers, (female) representatives, and tech-savvy accomplices. Only with the help of Anat, Athirat, and Kothar-wa-Hasis, Baal eventually finds himself as the one who reigns over the gods, and his powerful voice makes the earth shake and enemies flee.

Once again, Kothar-wa-Hasis features in the role of an expert hired to perform demanding and specific tasks to further Baal's goals. He produces gifts opulent enough to lure Athirat, he is the matchless architect who builds for Baal a palace without rival, and he is not only the one who knows why the palace needs a window but is even able to convince Baal about it. In all this, his role is auxiliary but independent; he works on assignment and not by force, without the need to fight for his position.

El's role may seem passive, but at the same time, he is the decisive agent in the palace episode. He does not act in any manner that would make him move from his place. He listens first to Anat, then to Athirat, giving both goddesses a friendly welcome with a touch of benign irony. El's supreme position is not really questioned, not even by Anat whose horrible threats sound too adolescent to El to exasperate him, let alone to shake his throne. The only thing El needs to do is to pronounce his word, and the building of the palace may begin. This makes his agency the most authoritative in the whole episode. 


\subsection{Baal versus Mot (KTU 1.5-6)}

Empowered by his newly erected palace and the authority it has given to him, Baal sends his messengers once again, this time to the Netherworld to convey his message to Mot. He needs to warn his messengers not to get too close to the god of death, lest he gobble them up like pieces of food. Much of the text is destroyed, but it is obvious that Mot receives the message proclaiming Baal's superiority. Mot replies in an aggravated tone, threatening to devour Baal for his unquenchable appetite:

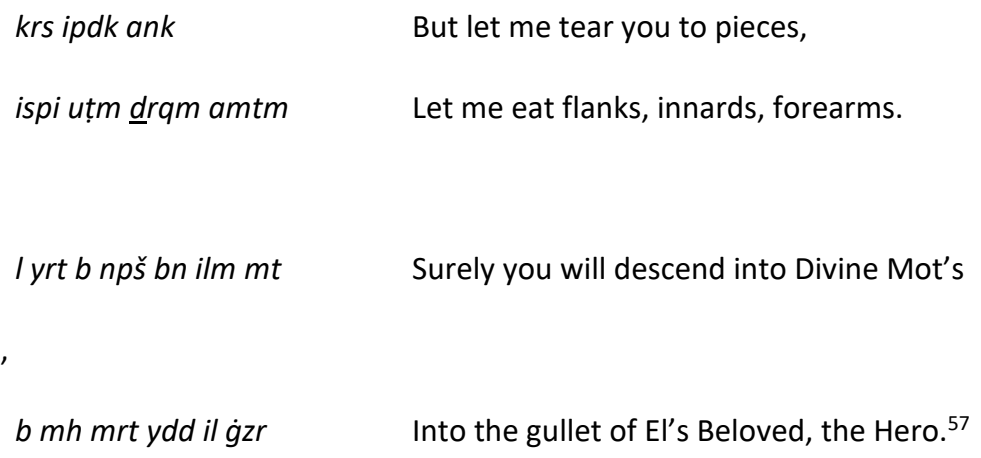

${ }^{57}$ KTU 1.5 | 4-8; I 31-35 (restored); cf. KTU 1.5 || 3-6. 
Mot frightens Baal off by insisting on an invitation to such a banquet, causing him to back off and send a new message to Mot with a directly opposite message: "Your servant am I, and yours forever" ('bdk an w d Imk)..$^{58}$ What is left of the text may suggest that a meal takes place, and that the assembly of the gods convenes. The first passage where the text becomes readable again is a command to Baal (presumably by El) to descend to the Netherworld together with all his weather-god apparatus (clouds, winds, bolts, and rains) and his daughters Pidray and Tallay, and accept his own death: “And you will know, O God, that you are dead" ( $w t d^{\prime}$ 'ilm $\left.k m t t\right) .{ }^{59}$ Before setting out on this humiliating journey, Baal intensely makes love with a heifer in the "field of Mot's realm" (šd šḥlm $m t),{ }^{60}$ begetting a son of which the preserved part of the text tells nothing more. Perhaps Baal wants to secure an heir for himself ${ }^{61}$ at the very site where

${ }_{4}^{58} K T U 1.5$ II 12.

${ }_{4}^{59} K T U 1.5 \mathrm{~V} 16-17$.

Formatted: English (United States)

${ }^{60}$ KTU $1.5 \mathrm{~V} 18-19$ (cf. KTU 1.10 where Baal also mates with a cow). The heifer is Formatted: English (United States) often identified as Anat, whose affection for Baal is compared to that of a cow for her calf (see below, n. 63), but this has been rejected with good reason by, e.g., Walls 1991, 122-44 and Day 1999, 37.

61 Thus, e.g., Walls 1991, 124. 
he dies. After a long break in the tablet, the text continues with words, perhaps of messengers, reporting that Baal is found dead:

mgny I n'my arș $d b r \quad$ We came to the pleasant land of the outback, I ysmt šd šḥlm mt To the beautiful field of Mot's realm.

mginy / b / npl / arș $\quad$ We came upon Baal fallen to earth; mt aliyn bl Dead is Mightiest Baal, blq zbl blars $\quad$ Perished the prince, Lord of the Earth. ${ }^{62}$

The reaction of the gods is dramatic. El descends from his throne to perform mourning rituals torturing his body and crying: "Baal is dead! ... After Baal I will descend to the Netherworld" (b\% mt ... atr b\% ard barș). ${ }^{63}$ Anat, for her part, does not sit idle but sets forth hunting, eventually arriving to the field where Baal lies.

${ }^{62}$ KTU 1.5 VI 5-10. This is where Anat eventually finds Baal's body (KTU $1.5 \mathrm{VI}$ 28-31).

${ }^{63}$ KTU 1.5 VI 23-25.

Formatted: English (United States) 
She mourns with words identical to those of El, and with the help of Shapsh, she carries him to Sapan's summit and buries him.

When Anat has announced Baal's death to El, he commands Athirat to select one of his sons to be made king by him. The first candidate fails because he is too weak, and Athtar, the second candidate, becomes humiliated again. This time he is found too short to sit on Baal's throne, and he gives up voluntarily: "I cannot be king on the summit of Sapan" (I amlk b șrrt șpn). ${ }^{64}$ More candidates may show up, but the text is broken here. The next scene is the first one to explicitly mention the emotional love of Anat for Baal. ${ }^{65}$ She grabs the hem of Mot and pleads with him to give Baal up, but Mot only tells how he took him in his mouth. After several months, Anat seizes Mot again, this time killing him with a sword and destroying his dead body.

After a long break, the text continues with a dream of El in which he sees heavens raining oil and rivers running with honey, portending Baal's return. He tells Anat to go to Shapsh and ask her to look for Baal who must have been found safe and sound again in the missing part of the text, since he returns to his

\section{${ }_{4}^{64} K T U 1.6$ I 62.}

Formatted: English (United States)

\footnotetext{
65 "Like the heart of the cow for her calf, like the heart of the ewe for her lamb, so is the heart of Anat for Baal" (KTU 1.6 II 6-9, 28-30).
} 
royal throne, striking his divine adversaries with a mace. After seven years, Mot raises his voice, complaining to Baal about everything he had to undergo at the hands of Anat, whose name, however, he does not mention. Mot demands that Baal give up one of his brothers, but as it turns out after a long break, Baal gives Mot's own brothers for him to consume. This leads to a duel, which results in a standoff with both parties falling:

\begin{tabular}{|c|c|}
\hline yt $\underline{\text { n }} \mathrm{kgmrm}$ & They eye each other like fighters, \\
\hline$m t^{\prime} z b l^{\prime} z$ & Mot is fierce, Baal is fierce. \\
\hline yngḥn k rumm & They gore each other like buffalo, \\
\hline$m t ' z b l^{\prime} z$ & Mot is fierce, Baal is fierce. \\
\hline$y n \underline{t} k n k$ bthm & They bite each other like serpents, \\
\hline$m t^{\prime} z b l^{\prime} z$ & Mot is fierce, Baal is fierce. \\
\hline ymșhn $\mathrm{k}$ Ismm & They drag each other like runners, \\
\hline$m t q l b l q l$ & Mot falls, Baal falls. ${ }^{66}$ \\
\hline
\end{tabular}

${ }^{66}$ KTU 1.6 VI 16-22.

Formatted: Swedish (Sweden)

Formatted: Swedish (Sweden) 
This leads to the final scene of the Baal Cycle, in which Shapsh acts as the arbitrator, speaking to Mot on El's behalf and proclaiming his decision to put an end to Mot's kingship. Mot is scared and surrenders without argument: "Let Baal be enthroned [on] his royal [throne]" (b/ yțtbn [/ ksi] m/kh). ${ }^{67}$

Interestingly, the conclusion of the whole composition, possibly set in a ritual context, mentions neither El nor Baal, neither Anat nor Athirat, neither Yamm nor Mot, but celebrates the rule of Shapsh over the dead ancestors, or Rephaim (rpum). The last deity mentioned in the Baal Cycle is Kothar-wa-Hasis, of whom we now learn that he is actually the divine magician and diviner, which is quite in line with his extraordinary skills. ${ }^{68}$ The words $h b r$ and $d^{\prime} t$ could also be translated as "companion," friend," or the like; however, the very last lines refer to Kothar-wa-Hasis fulfilling his role as the divine magician, as he is said to expel Arsh and Tunnan, demons that Anat earlier claimed to have vindicated. ${ }^{69}$ This gives the conclusion of the Baal Cycle an apotropaic character.

\footnotetext{
${ }^{67}$ KTU 1.6 VI 33-34.

68 Thus Smith 1984; Dijkstra 1986.

${ }^{69}$ KTU 1.6 VI 51-53; Arsh and Tunnan are mentioned in KTU 1.3 III 40, 43.
} 
The third part of the Baal Cycle (KTU 1.5-6) is again about the fight for supremacy between two male gods, Baal and Mot, whose comportment could be characterized in terms of hegemonic masculinity, at least when it comes to martial bravery and persuasive speech. Both gods defy and challenge each other, addressing each other in a harsh tone. Baal demonstrates his fertility by having intercourse with the heifer. On the other hand, there are serious ruptures in the hegemonic image of both Baal and Mot. Both of them are afraid of each other and have to surrender. Both gods die and rise from the dead, and neither one comes out as the winner of the final combat. That Baal eventually becomes enthroned again is not his own doing; rather, it is the will of El to which Mot must submit. Thus, the ultimate authority remains with $\mathrm{El}$, whose distraught reaction to Baal's death already indicates his sympathy for Baal.

Even in the case of the combat between Baal and Mot, the agency of female deities is decisive in making things happen. While Athirat's role is restricted to introducing candidates for Baal's throne after his death, all of whom are destined to fail, Anat's agency is all the more important. Not only does she take the initiative to look for and bury Baal's dead body, she also kills Mot with a sword and completely destroys his body. Anat's performance is no less masculine than that of Baal or Mot. Her affectionate love for Baal could be interpreted as a feminine trait in her character, especially because it is described 
in motherly terms. However, Baal, too, has been found listening to songs about his own love, ${ }^{70}$ and what is told about the meeting of the two in the earlier episode suggests a warm encounter. ${ }^{71}$

A further interesting female character is Shapsh, the Divine Lamp, who earlier was said to burn by the power of Mot (b yd bn ilm mt) while Anat is looking for Baal's dead body, ${ }^{72}$ but who later helps Anat to find Baal's body. Shapsh eventually occupies the scene, proclaiming El's will to Mot and ruling over the ancestors. It seems that Mot has had to give up his reign of the Netherworld to Shapsh, the female deity who no longer burns by the power of Mot but rules the Rephaim independently, with Kothar-wa-Hasis as her right hand. Again, Kothar-wa-Hasis is there when his expert skills are needed, this time as an exorcist.

3. Masculinities and Male Agencies

\footnotetext{
${ }^{70}$ KTU 1.3 III 5-6.

${ }^{71}$ KTU 1.3 IV 38-46.

${ }^{72}$ KTU 1.6 II 24-25.
} 
Two basic types of male agency can be recognized in the Baal Cycle: the competitive and the non-competitive, both forming an important part of the narrative strategy.

Without divine rivalry, there would be little for the audience to relate to, hence the competition between male gods can be recognized as the driving force of the narrative composition. The chief representatives of competitive male agency are, of course, Baal and his two main contenders, Yamm and Mot-and even Athtar, albeit in a different way. Baal, Yamm, and Mot incorporate qualities usually associated with hegemonic masculinity, corresponding to the cultural ideal of being a man in a patriarchal society. Such qualities are typically of a belligerent nature, including physical strength and violent performance, but even persuasive and powerful words, which are sometimes enough to scare off the adversary. The battlefields of competitive male agency are also fields of honor and shame, where masculine performance is under constant threat of being undermined. ${ }^{73}$ Even the death of a god, as we have seen, does not mean the end of his existence or, rather, his functioning in the divine world; rather, a god's

\footnotetext{
${ }^{73}$ For examples of shame and undermining masculine performance in the Hebrew Bible, see Lipka 2017.
} 
death and the defilement of his body are symbols of the degradation caused by the defeat.

Athtar, on the other hand, is not killed but humiliated. Unlike Baal, he does not stand up to claim a palace for himself, but subserviently accepts El's orders mediated by Shapsh. He appears unfit for Baal's throne because his feet do not reach the footstool. Athtar thus represents the flipside of competitive male agency, playing the role of the loser. Manifestly lacking important characteristics of ideal male performance and, therefore, contenting himself with a lower status, he could be said to represent subordinate masculinity. Male agency is, however, not all about rivalry and competition for the highest position. There are two male characters in the Baal Cycle who do not need to fight with anyone for anything, and who, therefore, represent noncompetitive male agency. One is El, who is genuinely peerless. Unlike the youthful and vigorous male gods, El has no rival, he has no need to be concerned for his position that is not threatened by other deities. He is not even offended if another male god is referred to as "the ruler with none above him." If it is assumed that the Baal Cycle is about divine-royal succession, it is worth noting that El's throne is still not open for competition, and there is no sign of his resignation from his supreme position. It would be wrong, therefore, to characterize him as a deus otiosus who has given up active agency, since he is 
actually in charge of constructing divine hierarchies. He may be persuaded by female deities and he may change his mind, but it is his word that authorizes anyone to be put on the throne. El's agency in the Baal Cycle is based on his unquestioned authoritative position above divine rivalries. At the same time El, by being sui generis in the divine world, epitomizes something that is important even from the point of view of the theory of multiple masculinities: the virtual impossibility of achieving absolute and ultimate hegemony even by competitive means. $^{74}$

Another character who stays outside the conflicts of Baal and his adversaries is Kothar-wa-Hasis. Thanks to his expert position, he does not need to compete with any other god. He acts on assignment in the service of other gods, without, however, being really subordinate to them because his special skills and his technological progressiveness gives him an independent position. He is the one who celebrates with Shapsh at the end of Baal Cycle.

Male agency is in a constant interplay with female agency in the Baal Cycle. If non-dependence on women should be seen as a feature of ideal

\footnotetext{
${ }^{74}$ According to Smit, Creangă, and van Klinken $(2015,139-40)$, the ideal of hegemonic masculinity is, in fact, more fiction than reality.
} 
hegemonic masculinity, ${ }^{75}$ then we may notice that, while Yamm and Mot are not actively supported by any female deity and Athtar does not have a wife, ${ }^{76}$ Baal's success is essentially dependent on the assistance of Anat and Athirat, indirectly even by Shapsh. The hegemonic competition does not depend on male agency alone; on the contrary, the significance of the agency of the female deities for the narrative strategy in the Baal Cycle can hardly be overestimated. ${ }^{77}$ They function actively in virtually all decisive turns of the narrative, and their agency is far from that of subservient helpers. This gives the female deities an essential, proactive role in the construction of hegemony in the Baal Cycle. Baal's rule in particular has been made dependent on their initiative.

The Baal Cycle shows that masculine performance, that is, acting in a way that corresponds to what can be expected of a quintessential male actor in a given context, is not restricted to male agency. Of the main female characters, Athirat's actions can hardly be characterized as masculine since she performs the role of the divine wife, and even Shapsh does not act in a distinctly masculine manner despite her grand finale as the ruler of the Rephaim. Anat, however, as

\footnotetext{
${ }^{75}$ Cf. Clines 1995, 225-27.

${ }^{76}$ KTU 1.2 III 22: "But you have no wife li[ke the gods...] (wn in attt [I]k km [ilm]).

77 Cf. Korpel 1998, 106; Budin 2018, 69-70.
} 
we have seen many times, performs in a way that fully corresponds to the action of the male characters in the Baal Cycle. She behaves aggressively, and her martial prowess is remarkable. She kills Mot and appears determined enough to challenge El himself. Nevertheless, she does not express aspirations for power. She does not compete for her own sake but fights for Baal, hence her masculine performance functions in tandem with Baal's. This places the male and the female protagonist in a reciprocal and heterarchical position: ${ }^{78}$ Anat's masculine performance could be described as auxiliary or even subordinate, but Baal would get nowhere without her. In fact, Baal depends on Anat much more than Anat does on him. ${ }^{79}$

This analysis of the Baal Cycle corroborates the category of hegemonic masculinity as the basic type against which the other types of masculinity are measured but which, however, is not a uniform block. The main theme of the narrative is pursuit of hegemony, but at the same time, the text knows both competitive and non-competitive male agencies. The throne of Baal represents the kind of hegemony Baal, Yamm, and Mot have to compete for, the kind of

\footnotetext{
${ }^{78}$ Cf. Juloux 2016.

${ }^{79}$ This may reflect the political dependence of royal men on their relationships to royal women; see Thomas 2019.
} 
hegemony that is precarious, constantly threatened, and often in need of help. ${ }^{80}$ El represents another kind of hegemony that is beyond the reach of other gods and, therefore, beyond competition. Kothar-wa-Hasis, again, takes part in the game of thrones from a position that is too autonomous to be presented as representing complicit, let alone subordinate masculinity. His hegemony, if it may be called as such, is based on his personal qualities that make him irreplaceable and cause the other characters, however hegemonic, to rely on him. Hence Kothar-wa-Hasis, while not executing hierarchical power, may be the most independent character in the entire composition. Finally, the categories are muddled up by Anat's masculine performance, ${ }^{81}$ which divorces masculinity from

\footnotetext{
${ }^{80}$ This competition has been interpreted in political terms either as a critical reflection on the hierarchical principle of the Ugaritic monarchy (Tugendhaft 2012; 2018), or as reflecting the generally unstable nature of the institution of kingship (Töyräänvuori 2018, 227).

${ }^{81}$ This also happens in Aqhat, where not only Anat's performance is masculine, but even Pughat, Aqhat's sister, transgresses gender boundaries: "The girl is deliberately rendered androgynous" (Budin 2018, 67; cf. Smith 2014, 129).
} 
male gender ${ }^{82}$ and helps to remove gender essentialism from the concept of masculinity. ${ }^{83}$

The network of male agencies and masculine performances in the Baal Cycle is complex enough not to construct a simple hierarchy of more or less hegemonic male actors in this divine drama. Thanks to this complexity, the Baal Cycle-together with other texts from Ugarit, mostly still waiting to be analyzed from the point of view of masculinity studies - helps us revisit some patterns and categories of masculinity that have been used as tools in recent analyses of masculinities in biblical and ancient Near Eastern sources.

\section{Works Cited}

Asher-Greve, Julia M. 2018. "From La Femme to Multiple Sex/Gender." Pages 15-50 in Studying Gender in the Ancient Near East. Edited by Saana Svärd and Agnès Garcia Ventura. University Park, PA: Eisenbrauns.

\footnotetext{
${ }^{82}$ Anat is also different from the kind of female masculinity that involves lesbian or transgender performance; see Halberstam 1998.

${ }^{83}$ For the problems of reading ancient text with the help of modern gender categories, see Asher-Greve 2018; Zsolnay 2018.
} 
Asikainen, Susanna. 2014. “'Eunuchs for the Kingdom of Heaven': Matthew and Subordinated Masculinities." Pages 156-88 in Biblical Masculinities Foregrounded. Edited by Ovidiu Creangă and Peter-Ben Smit. HBM 62. Sheffield: Sheffield Phoenix Press.

Budin, Stephanie Lynn. 2018. "Gender in the Tale of Aqhat." Pages 51-72 in Studying Gender in the Ancient Near East. Edited by Saana Svärd and Agnès Garcia Ventura. University Park, PA: Eisenbrauns.

Butler, Judith. 1990. Gender Trouble: Feminism and the Subversion of Identity. New York: Routledge.

Carrigan, Tim, Bob Connell, and John Lee. 1985. "Toward a New Sociology of Masculinity." Theory and Society 14:551-604.

Chapman, Cynthia R. 2004. The Gendered Language of Warfare in the IsraeliteAssyrian Encounter. HSM 62. Winona Lake, IN: Eisenbrauns.

Clines, David J. A. 1995. Interested Parties: The Ideology of Writers and Readers

Formatted: English (United States) of the Hebrew Bible. JSOTSup 205. Sheffield: Sheffield Academic Press.

Connell, R. W. 2005. Masculinities. Second Edition. Berkeley: University of California Press.

Connell, R. W., and James W. Messerschmidt. 2005. “Hegemonic Masculinity: Rethinking the Concept." Gender and Society 19:829-59. 
Cooper, Jerrold S. 2002. "Buddies in Babylonia: Gilgamesh, Enkidu, and Mesopotamian Homosexuality." Pages 73-85 in Riches Hidden in Secret Places: Ancient Near Eastern Studies in Memory of Thorkild Jacobsen. Edited by Tzvi Abusch. Winona Lake, IN: Eisenbrauns.

Cornelius, Izak. 1994. The Iconography of the Gods Reshef and Baal: Late Bronze and Iron Age I Periods (c. 1500-1000 BCE). OBO 140. Fribourg: University Press Fribourg and Göttingen: Vandenhoeck \& Ruprecht.

Creangă, Ovidiu, ed. 2010. Men and Masculinity in the Hebrew Bible and Beyond. BMW 33. Sheffield: Sheffield Phoenix Press.

Creangă, Ovidiu, ed. 2019. Hebrew Masculinities Anew. HBM 79. Sheffield: Sheffield Phoenix Press.

Creangă, Ovidiu, and Peter-Ben Smit, eds. 2014. Biblical Masculinities Foregrounded. HBM 62. Sheffield: Sheffield Phoenix Press.

Day, Peggy L. 1991. “Why Is Anat a Warrior and Hunter?” Pages 141-46, 329-32 in The Bible and the Politics of Exegesis: Essays in Honor of Norman $K$. Gottwald on His Sixty-Fifth Birthday. Edited by David Jobling, Peggy L. Day, and G. T. Sheppard. Cleveland: Pilgrim Press.

Day, Peggy L. 1999. "Anat." Pages 36-43 in Dictionary of Deities and Demons in the Bible. Edited by Karel van der Toorn, Bob Becking, and Pieter W. van der Horst. Second edition. Leiden: Brill. 
de Moor, Johannes C. 1987. Anthology of Religious Texts from Ugarit. Nisaba 16. Leiden: Brill.

Dietrich, Manfried, Oswald Loretz, and Joaquín Sanmartín. 2013. Die keilalphabetischen Texte aus Ugarit, Ras Ibn Hani und anderen Orten: Dritte, erweiterte Auflage / The Cuneiform Alphabetic Texts from Ugarit, Ras Ibn Hani and Other Places: Third, Enlarged Edition. AOAT 360/1. Münster: Ugarit-Verlag.

Dijkstra, Meindert. 1986. “Once Again: The Closing Lines of the Ba'al Cycle." UF $17: 147-52$.

Guest, Deryn. 2011. “From Gender Reversal to Genderfuck: Reading Jael through a Lesbian Lens." Pages 9-43 in Bible Trouble: Queer Reading at the Boundaries of Biblical Scholarship. Edited by Teresa J. Hornsby and Ken Stone. SemeiaSt 67. Atlanta: Society of Biblical Literature.

Guest, Deryn. 2016. “Modeling the Transgender Gaze: Performances of Masculinities in 2 Kings 9-10." Pages 45-80 in Transgender, Intersex, and Biblical Interpretation. Edited by Teresa J. Hornsby and Deryn Guest. SemeiaSt 83. Atlanta: SBL Press.

Halberstam, Judith. 1998. Female Masculinity. Durham, NC: Duke University Press. 
Juloux, Vanessa. 2016. “Prolégomènes à l'étude des relations de pouvoir entre les entités animées dans KTU 1.1-6: Cadre relationnel de 'Anatu et Ba'lu." Res Antiquae 13:123-64.

Korpel, Marjo C. A. 1998. "Exegesis on the Work of Ilimilku of Ugarit." Pages 86111 in Intertextuality in Ugarit and Israel. Edited by Johannes C. de Moor. Leiden: Brill.

Krondorfer, Björn, ed. 2009. Men and Masculinities in Christianity and Judaism: $A$ Critical Reader. London: SCM Press.

Lipka, Hilary. 2017. "Shaved Beards and Bared Buttocks: Shame and the Undermining of Masculine Performance in Biblical Texts." Pages 176-97 in Being a Man: Negotiating Ancient Constructs of Masculinity. Edited by Ilona Zsolnay. London: Routledge.

Macwilliam, Stuart. 2019. "Final Reflections on Hebrew Masculinities Anew." Pages 293-300 in Creangă 2019.

Marsman, Hennie J. 2003. Women in Ugarit and Israel: Their Social and Religious Position in the Context of the Ancient Near East. OtSt 49. Leiden: Brill.

Moore, Stephen D., and Janice Capel Anderson, eds. 2003. New Testament Masculinities. SemeiaSt 45. Atlanta: Society of Biblical Literature.

Nissinen, Martti. 1998. Homoeroticism in the Biblical World: A Historical Perspective. Minneapolis: Fortress Press. 
N’Shea, Omar. 2018. “Empire of the Surveilling Gaze: The Masculinity of King Sennacherib." Pages. 315-35 in Studying Gender in the Ancient Near East. Edited by Saana Svärd and Agnès Garcia Ventura. University Park, PA: Eisenbrauns.

\section{Pardee, Dennis. 2012. The Ugaritic Texts and the Origins of West-Semitic Literary}

\section{Composition. The Schweich Lectures of the British Academy 2007. Oxford:}

\section{Oxford University Press.}

Peled, Ilan. 2016. Masculinities and Third Gender: The Origins and Nature of an Institutiuonalized Gender Otherness in the Ancient Near East. AOAT 435. Münster: Ugarit-Verlag.

Pitard, Wayne T. 2013. "The Combat Myth as a Succession Story at Ugarit." Pages 199-205 in Chaos and Cosmos: A Reassessment of Hermann Gunkel's Chaoskampf. Edited by JoAnn Scurlock and Richard Beal. Winona Lake, IN: Eisenbrauns.

Smit, Peter-Ben, Ovidiu Creangă, and Adriaan van Klinken. 2015. "The Reception of the Bible and the Construction of Masculinities in Jewish and Christian Con/Texts." Journal of the Bible and Its Reception 2:197-218.

Smith, Mark S. 1984. "The Magic of Kothar, the Ugaritic Craftsman God, in KTU 1.6 VI 49-50." RB 91:377-80.

Smith, Mark S. 1986. “Interpreting the Baal Cycle." UF 18:330-39. 
Smith, Mark S. 1994. The Ugaritic Baal Cycle, Volume I: Introduction with Text, Translation, and Commentary of KTU 1.1-1.2. VTSup 55. Leiden: Brill.

Smith, Mark S. 1997. "The Baal Cycle." Pages 81-180 in Ugaritic Narrative Poetry. Edited by Simon B. Parker. SBLWAW 9. Atlanta: Society of Biblical Literature.

Smith, Mark S. 1998. "The Death of 'Dying and Rising Gods' in the Biblical World: An Update with Special Reference to Baal in the Baal Cycle." SJOT 12: 257-313.

Smith, Mark S. 2001. The Origins of Biblical Monotheism: Israel's Polytheistic Background in the Ugaritic Texts. New York: Oxford University Press.

Smith, Mark S. 2003. "When the Heavens Darkened: Yahweh, El, and the Divine Astral Family in Iron Age II Judah." Pages 265-77 in Symbiosis, Symbolism, and the Power of the Past: Canaan, Ancient Israel, and Their Neighbors from the Late Bronze Age through Roman Palaestina. Edited by William G. Dever and Seymour Gitin. Winona Lake, IN: Eisenbrauns.

Smith, Mark S. 2008. "Sacred Marriage in the Ugaritic Texts? The Case of KTU/CAT 1.23 (Rituals and Myths of the Goodly Gods)." Pages 93-113 in Sacred Marriages: The Divine-Human Sexual Metaphor from Sumer to Early Christianity. Edited by Martti Nissinen and Risto Uro. Winona Lake, IN: Eisenbrauns. 
Smith, Mark S. 2014. Poetic Heroes: Literary Commemorations of Warriors and Warrior Culture in the Early Biblical World. Grand Rapids, MI: Eerdmans. Smith, Mark S., and Wayne T. Pitard. 2009. The Ugaritic Baal Cycle, Volume II: Introduction with Text, Translation, and Commentary of KTU/KTU 1.3-1.4. VTSup 114. Leiden: Brill.

Svärd, Saana, and Agnès Garcia Ventura, eds. Studying Gender in the Ancient Near East. University Park, PA: Eisenbrauns.

Svärd, Saana, and Martti Nissinen. 2018. “(Re)constructing the Image of the Assinnu." Pages 373-411 in Studying Gender in the Ancient Near East. Edited by Saana Svärd and Agnès Garcia Ventura. University Park, PA: Eisenbrauns.

Thomas, Christine Neal. 2019. “Gender and Politics at Ugarit: The Undoing of the Daughter of the Great Lady." JAOS 139:287-305.

Töyräänvuori, Joanna. 2017. “The Royal Adoption Scene in Ugaritic and Biblical Texts." Pages 247-57 in Fortune and Misfortune in the Ancient Near East: Proceedings of the $60^{\text {th }}$ Rencontre Assyriologique Internationale at Warsaw 21-25 July, 2014. Edited by Olga Drewnowska and Małgorzata Sandowicz. Winona Lake, IN: Eisenbrauns.
Formatted: Swedish (Sweden)

Formatted: English (United States) 
Töyräänvuori, Joanna. 2018. Sea and the Combat Myth: North West Semitic Political Mythology in the Hebrew Bible. AOAT 457. Münster: UgaritVerlag.

Tugendhaft, Aaron. 2012. "Unsettling Sovereignty: Politics and Poetics in the Baal Cycle." JAOS 132:367-84.

Tugendhaft, Aaron. 2018. Baal and the Politics of Poetry. London: Routledge.

Walls, Neal H. 1991. The Goddess Anat in the Ugaritic Myth. SBLDS 135. Atlanta: Scholars Press.

Washington, Harold. 1997. "Violence and Construction of Gender in the Hebrew Bible: A New Historicist Approach." Biblnt 5: 324-63.

Wilson, Stephen M. 2019. “Biblical Masculinity Studies and Multiple Masculinities Theory: Past, Present, and Future." Pages 19-40 in Hebrew Masculinities Anew. Edited by Ovidiu Creangă. HBM 79. Sheffield: Sheffield Phoenix Press.

Wyatt, Nicholas. 2005. "There's Such a Divinity Doth Hedge a King": Selected Essays of Nicolas Wyatt on Royal Ideology in Ugaritic and Old Testament Literature. Aldershot, UK: Ashgate.

Zsolnay, Ilona. 2018. “Analyzing Constructs: A Selection of Perils, Pitfalls, and Progressions in Interrogating Ancient Near Eastern Gender." Pages 461- 
79 in Studying Gender in the Ancient Near East. Edited by Saana Svärd and Agnès Garcia Ventura. University Park, PA: Eisenbrauns.

Zsolnay, Ilona, ed. 2017. Being a Man: Negotiating Ancient Constructs of Masculinity. London: Routledge. 